International Journal of Instruction

e-ISSN: 1308-1470 • www.e-iji.net

Article submission code:

2020072108221

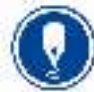

July $2021 \bullet$ Vol.14, No.3

p-ISSN: 1694-609X

pp. 567-582

Received: 21/07/2020

Revision: 04/01/2021
Accepted: 28/01/2021

OnlineFirst: 05/06/2021

\title{
Working on Primary School Teachers' Preconceptions of Organizational Climate and Job Satisfaction
}

\section{Hareesol Khun-inkeeree}

Asst. Prof., School of Languages and General Education, Walailak University, Thailand, sol.khun75@gmail.com

\section{Mohd Faiz Mohd Yaakob}

School of Education, Universiti Utara Malaysia, Malaysia.Mohd.faiz@uum.edu.my

\section{WanRozimi WanHanafi}

School of Education, Universiti Utara Malaysia, Malaysia, ewann76@yahoo.com

\section{Mat Rahimi Yusof}

School of Education, Universiti Utara Malaysia, Malaysia. mrahimiy@uum.edu.my

\section{S. Omar-Fauzee}

School of Education, Universiti Utara Malaysia, Malaysia.mohdsofian@uum.edu.my

The aim of this study is to identify positive and negative feedback from teachers on their perception of the school's organizational climate and job satisfaction. A mix-method approach was used to examine it; a survey method (220 teachers) and a semi-structured interview (20 teachers) were used. Teacher Job Satisfaction Questionnaires was employed to measure teacher job satisfaction. The quantitative study found that there was a significant relationship between all dimensions of organizational (climate student relationship, collaboration, decision-making, educational innovation, and school resources) and job satisfaction. These dimensions also emerged in the Interview content analysis on positive and negative feedback from the organizational climate themes affecting their job satisfaction. Recommendations for further studies are also suggested.

Keywords: positive and negative perception, school organizational climate, teacher job satisfaction, primary school teacher, teachers

\section{INTRODUCTION}

Malaysian Education Development Plan 2013-2025 is a comprehensive national education program to deliver educational institutions' quality, educational excellence and physical growth (Eh Tem, 2013; Judge, Weiss, Kammeyer-Mueller, \& Hulin, 2017, Ministry of Education, 2013). It acts as an agent for the creation of the intended prediction that needs education reform to fulfill the mandate to achieve the vision and

Citation: Khun-inkeeree, H., Yaakob, M. F. M., WanHanafi, W., Yusof, M. R., \& Omar-Fauzee, M.S. (2021). Working on perception of primary school teacher on organizational climate and their job satisfactions. International Journal of Instruction, 14(3), 567-582. https://doi.org/10.29333/iji.2021.14333a 
mission to academic excellence through compulsory awareness (Entoh \& Abdullah, 2019). In order to transpire it to happen, teachers support will play a major part in educating children through their engagement, inspiration and teaching skills to ensure the achievement of country education goals (Bai, Piri \& Piri, 2014). In addition to the instructor element, the school's atmosphere and the school's climatic influences also play a key role in influencing the organization's climate excellence (Wynn, 2019). The school environment is a social, physical, infrastructural, teaching and emotional environment that creates an atmosphere that is calm, relaxed and friendly (Kariming \& Ambatong, 2019). Such variables enable the school to do it as it is closely connected to the pleasant and relaxed atmosphere of the school.

In order to build a favorable school climate, it is important that school leaders learn to prepare for the right transitions, wisdom and innovation in order not just to create a safe school atmosphere, but also to make it enjoyable for teachers (Amedome, 2018). Moreover, Eng Fei and Han (2018) endorse the results of the Amedome report, which suggest that a healthy learning atmosphere can be considered conducive at learning. This relaxed state indirectly affects teachers and students to build a pleasant culture of learning that also impacts their positive place on the school. That means that teachers who are highly satisfied and happy at school also offer their support and teaching commitment. It means that the academic success of students increases. Similarly, Valdez, Guro, Cana, and Lawi (2019) found that the environment of the school has a direct relation with work satisfaction. To do so, head leaders have to cultivate optimistic and empowering workers (Valdez, et al., 2019). This demonstrates, therefore, that the success of the school is highly affected by a favorable and supportive school setting.

\section{Research Problem}

The organizational culture of schools where teachers and staff do not respect their workenvironments are closely related to school teachers' unhappiness, which leads to the school's lack of vision and purpose. Therefore, the Instructor's contentment is essential to boost the organization's effectiveness. Organisation, according to Valdez, et al. (2019) mainly affects the personality of the individual. McLaughlin (2018), also suggests that the organisation's environment is multifaceted and can be categorized in various ways, such as individual, administrative, innovation-driven and goal-oriented. It is also endorsed. It indicates that the school atmosphere leads to corporate success and employee enjoyment. Furthermore, the organizational environment and employee satisfaction also play the significant part in organizational performance (Wynn, 2019). Nevertheless, many school institutions often lack the elements to create a favorable school atmosphere that affects the satisfaction of teachers. Hassan and Wahab's (2017) reported that they found the satisfaction of teachers to be doubtful because of the weak organizational climate. The unequal school atmosphere has led the teacher in their teaching jobs to feel less confident.

The fact that the school needs funding which could not have taken place in their place of employment is one of the factors that are awkward. Furthermore, a study in the Malaysian Education Development Plan 2013-2025 roadmap revealed that the Ministry 
was aware of substantial gaps in school infrastructure growth (Ministry of Education, 2013). Many schools lack the new facilities required to efficiently teach and train to meet potential workforce requirements. The Malaysia Education Development Plan roadmap study for 2013-2025 also reveals that nearly 2,000 have no science laboratories and 2,700 schools have no computer labs (Ministry of Education, 2013). This research is important to investigate the organisation's environment and teacher satisfaction in Alor Janggus area, Kedah due to this problem. However, Hamdan and Hamzah (2016) found that the teacher teaching ineffectiveness, the inability to deliver conveniently, and weak organizational conditions to all schools is still a consideration that the Ministry of Education must fully grasp. This argument is also backed by Kapa and Gimbert (2017) who demonstrate the unfulfilled working conditions of teachers in most schools. This shows that the teacher's attention would be on the happiness of teaching employees that was inter-related to the good working atmosphere (Amedome, 2018; Hardianto, 2019).

Another critical problem was the enthusiasm of head teachers who only wanted to see school's academic performance by neglecting teacher satisfaction (Azmi \& Siren, 2016). There must therefore be a place for head teachers to balance an organization's positive atmosphere with teachers 'job satisfaction. This recommendation is consistent with the Ministry of Education (2013), which calls on teachers to build classrooms with a sound environment and atmosphere. There are still problems because the school organization climate, in particular for the schools in Kedah, Malaysia, has not examined thoroughly regarding the element of teacher satisfaction and dissatisfaction. This research will allow the State Department of Education in Kedah to create a special curriculum, which will further boost the academic performance of students. Hence, the aim of this study is to identify teachers 'positive and negative feedback on their perception of the school's organizational environment and job satisfaction.

\section{METHOD}

Data were collected for this analysis using two methodologies; quantitative and qualitative approaches. To illustrate the two methodologies, they are divided into separate sub-themes as follows:

Study One: Quantitative Studies:

\section{Samples}

A quantitative approach with a cross-sectional survey method was used with a standardized questionnaire as a survey tool. This study involved schools in Alor Janggus district, Kedah. In Alor Jangus, there were 23 primary schools with 516 teachers. According to Krejcie and Morgan's (1970) sampling process, when the population size is below 516, the sample size is 220. 220 samples involved in this study.

\section{Instruments}

For this study, the researcher prepared a questionnaire containing three parts, part A for teacher demographics, used to assess teacher personal information. Part B is used to obtain information on the climate of the school organization containing 21 items. The School Level Environment Questionnaires (SLEQ) tools developed by Johnsons et al (2007) are used to measure the organizational climate. Five organizational climate 
dimensions and internal consistency (alpha Cronbach) : cover collaboration (.84), student relationship (.82), school resource (.85), decision-making (.81) and educational innovation (.87). Whereas, Section $\mathrm{C}$ consisting of Teacher Job Satisfaction Questionnaires (TJSQ) developed by Lester (1982) is used to measure teacher satisfaction. The teacher satisfaction instrument consists of 66 items. The reliability of the TJSQ is equal to the value of Alpha Cronbach of .88. All questions use a 5-point Likert scale from 1-Strongly Disagree to 5-Strongly Disagree.

\section{Research Procedures}

Prior to the actual study, the researcher performed a pilot study of 30 teachers in one of the schools outside Alor Janggus. The real research did not include these respondents. The purpose of performing the pilot study is to assess the instrument reliability and seek input from respondents if any of the questions are difficult to understand, ambiguous, and inappropriate. With the feedback, the instrument was checked again before the actual analysis was performed. Alpha Cronbach score for all organizational environment dimensions is between .80-.93; while work satisfaction is .87. Therefore, the researchers must obtain permission from the Education Policy Research and Planning Division (EPRD) who acted as ethical committee in advance of the study to begin the data collection process. The electronic application with the plan and questionnaire was sent to EPRD for the school's approval for conducting research. In about a week, an EPRD approval letter was received via personal email address of researcher. The researchers sent formal requests to Kedah State Education Department (KSED) to comply with the law. After receiving the letter from the Kedah State Department of Education, the researcher individually tried to get permission from the head teacher to collect data from teachers teaching in schools selected by stratified random sampling. The head teachers named a senior assistant teacher as the coordinator to administer the questionnaire to the students. After one week, the researcher took the form for review through the senior assistant. The form was pre-checked to ensure that the form was correct and all questions were answered with just one answer chosen. The teachers returned the completed 220 questionnaires to senior researcher assistance or data analysis.

Study Two: Qualitative studies

\section{Sample}

The researcher used semi-structured questionnaires based on the dimensions of the previous literature review. Twenty teachers who participated in the first study (Quantitative Survey Methodology) agreed to be interviewed. They were asked to sign an informed consent letter, which agreed that the interviewees would be recorded by the researchers. Interviews were conducted at the school, as agreed by both parties.

\section{Procedure}

Out of 220 primary school teachers participating in survey research, a group of 20 primary school teachers were selected for interview sessions. The interview session accompanied the completion of survey questions as conducted within the first week. Investigators conducted the interviews which lasted 30-40 minutes. Follow-up interviews if clarification was needed. All participants gave their consent to tape 
recorded the interviews, and the researcher ensured the confidentiality of primary school teachers was maintained. The information was transcribed from each interview's audio tapes. In this study, the researchers developed interview questions based on previous literature findings. They confronted the school community's organizational climate and job satisfaction as follows;

a. Do you think you're satisfied with your work right now? How, why not?

b. What are your thoughts on teachers and students' relationship in your school? Why does this happen?

c. What do you think about teaching innovation in your school's organizational environment? Why is that?

d. What's your approach to the organizational climate in school decision-making? What's the reason why?

e. How does the relationship between administrators, teachers and students relate to the school organization? Why is that so?

f. What are your thoughts on school resources and facilities for teaching and learning? Why is this happening?

g. What are your general views on your school's teacher satisfaction and organizational environment? What is the explanation for that?

Those questions were used to collect information about teachers who understood their own school teaching emotions and experiences, and how these beliefs were affected. Most of the questions were answered as a follow-up to the teacher's answers or explanations. Until inclusion in the actual study, two teachers checked the questions. Interviews were administered separately and collectively. A detailed line-by-line analysis was used to construct initial categories and suggested inter-category relationships. Text analysis means was conducted eollected using the coding process. Initially, free coding was used. The data were divided based on questions, followed by related events grouped together as a theme, assigning a single conceptual mark or category. The data on the positive and negative feedback of the themes were compared. As the questions were centered on previous research dimensions, some of the answers were based on the previous analysis of the thematic themes listed earlier. Using specific coding methods for their positive or negative perception, categories were integrated to create a general framework for subsequent topics.

\section{FINDINGS AND DISCUSSION}

\section{Respondents Profile}

The followings are the profile of the respondents which includes: sex, age, teaching experience, education and working with the current headmasters. See Table 1

Table 1

The demographic profile of the respondents

\begin{tabular}{rlll}
\hline \multicolumn{2}{c}{ Variables } & Respondents N=220 & $\%$ \\
\hline Sex & Male & 106 & 48.2 \\
Female & 114 & 51.8 \\
\hline Age Range 20 to 30 year & 3 & 1.4 \\
& 31 to 40 year & 73 & 33.2 \\
41 to 50 year & 119 & 54.1 \\
51 to 60 year & 25 & 11.4 \\
\hline
\end{tabular}


The Significance Difference among Demographic Variable and Teacher Job Satisfaction

The statistics for the two groups of teacher's gender indicated that there was no the statistics for the two groups of teachers' gender indicated that there was no significant difference for the independent $t$-test. This test found [ $t(218)=-.209$,

$\mathrm{p}=.80(\mathrm{P}>.05)]$. Whereas, the ANOVA test found no significance $[\mathrm{F}(3.216)=$ $1.98, \mathrm{P}>.05$ ] between teacher age and teacher satisfaction level. Furthermore, the ANOVA test found no significant difference $[\mathrm{F}(2,217)=.038, \mathrm{P}>.05]$ between teacher teaching experience and teacher job satisfaction. This shows that gender, age and teaching experience among teachers do not have any differences.

\section{The Overall Result of Quantitative and Qualitative}

The Relationship between the Organizational Climate Dimensions and the Teacher Job Satisfaction

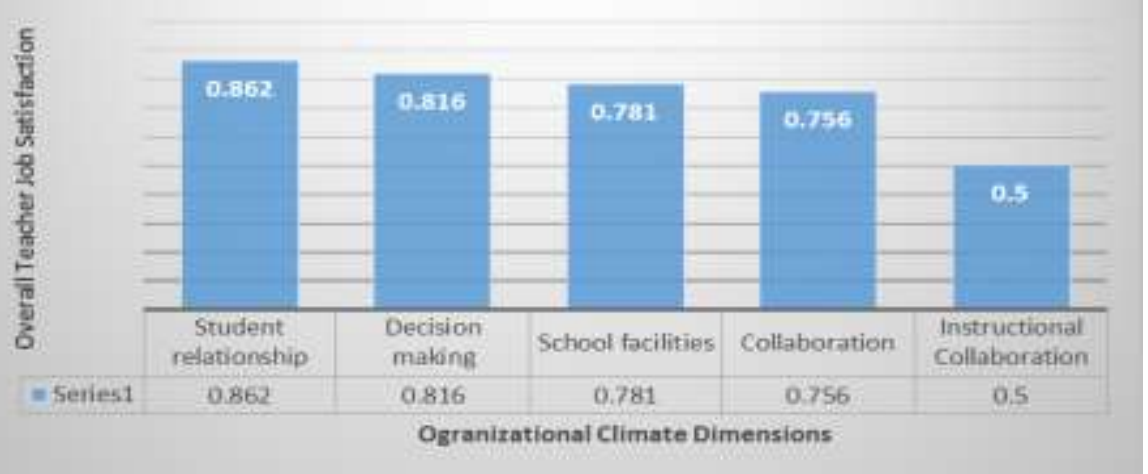

Figure 1

The Pearson correlation score of the dimensions of organizational climates and teacher job satisfaction

The Pearson correlation score of the dimensions of organizational climates and teacher job satisfaction are as follows (See Figure 1): Students relationship $(\mathrm{r}=.862$, $\mathrm{p}=.0001)$, decision making $(\mathrm{r}=.816, \mathrm{p}=.0001)$, school facilities $(\mathrm{r}=.781, \mathrm{p}=.0001)$, collaboration $(\mathrm{r}=.756, \mathrm{p}=.0001)$, instructional innovation $(\mathrm{r}=.500, \mathrm{p}=.0001)$. The findings from the Pearson Correlation analysis show that there are significant relationships among the five dimensions in the school organization climate and the teacher satisfaction in the Alor Janggus area, Kedah. This means that the dimensions of collaboration, student relationships, school resources, decision making and instructional innovation are related to the level of teacher job satisfaction. Thus, in order to achieve high levels of job satisfaction, the school organization climate must be at a level that provides maximum satisfaction to the organization. It is undeniable that the organizational climate has a profound impact on the success and failure of an organization. According to Kapa and Gimbert (2020) the organizational climate of the school is an important element in the success accomplishments of the school with its students. 
The Positive and Negative Feedback by Teachers towards Organizational Climate and Teacher Job Satisfaction (Qualitative results)

Teachers become pleased with their preferred career path. There are, however, both positive and negative perceptions which influence this public impression. Findings from Kapa and Gimbert, (2020) noted that a school environment where rules are put in place by both teachers and the administration can have a positive impact on how teachers feel about their jobs. According to Katsantonis (2019) school climate contributes significantly, amongst other considerations, to students' performance, teacher working enjoyment, teachers' desire to endure productively, and outstanding school environment. Thus, school climate has been perceived by teachers as an vital ingredient of making teacher work happily. The content analysis also found that the themes that emerged from content analysis based on the positive and negative feedbacks (Figure 2) of organizational climate themes influencing their job satisfaction are; student relationship $(+\mathrm{ve}=150,-\mathrm{ve}=10)$, collaboration $(+\mathrm{ve}=123$; -ve $=12)$, decision making $(+v e=76,-v e=25)$, Instructional Innovation $(+v e=55$, $\mathrm{ve}=18)$, and school resources $(+\mathrm{ve}=38,-\mathrm{ve}=33)$.

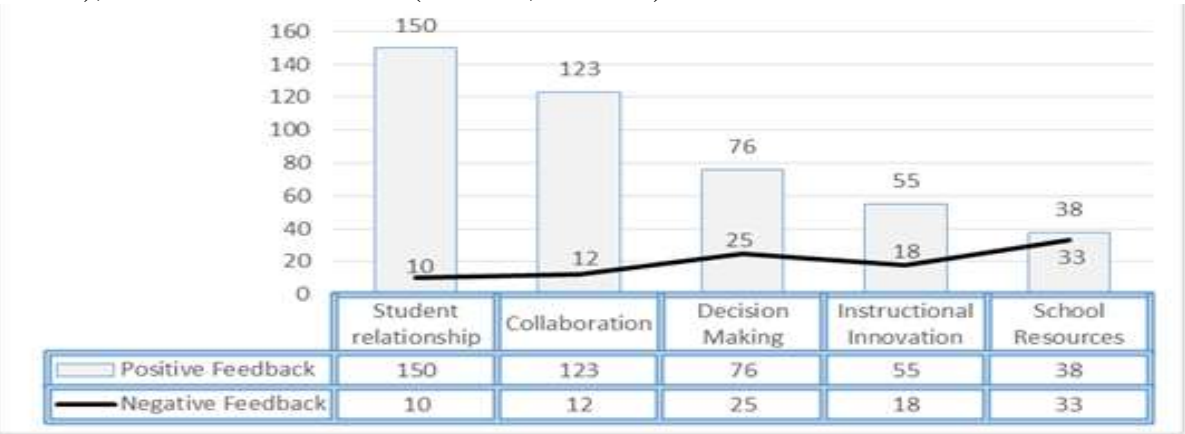

Figure 2

The positive and negative feedback by teachers

\section{The Organizational Climate and Job Satisfaction}

According to Locke (1969), job satisfaction is defined as the level of happiness, enjoyment, and perceived value that a person obtains via his career or everyday labour. Furthermore, work situations such as duty assigned to teachers, support staff, classroom and behavioural management support, relationships with colleagues, resource quality, and class size are frequently identified as the most significant factors influencing teacher job satisfaction (e.g., Amedome, 2018; Eng Fei \& Han, 2018; Hardianto, 2019; Maiti, 2019; Mukhtar, 2020; Yusoff \& Saidin, 2016). According to Maiti (2019), negative and positive attitudes can influence a variety of dimensions of organisational behaviour in the workplace. The relevance of work satisfaction in the company has been proven, particularly in terms of employee relations, turnover, absenteeism, productivity, and efficiency. Achieving personal commitment and professional aspiration in the teaching profession is essential, as it relates to more constructive job performance (Katsantonis, 2019). On the other hand, dissatisfaction with teaching work leads to a lower degree of motivation and less 
desire to remain in the teaching profession (Kariming \& Ambatong, 2018). Satisfaction or dissatisfaction with teaching can result from interaction with students, collaboration with fellow students and parents, or from experience such as an effective interactive lesson (Kapa \& Gimbert, 2017; Mukhtar, 2020). Learning environments also determine the job satisfaction of the teacher and the impact of the student learning process (Eng Fei \& Han 2018; Hassan \& Wahab 2017; Stewart \& Robles-Piña 2008; Yusoff \& Saidin 2016). The Interview themes that emerged include: student relationship, collaboration, decision-making, educational innovation, and school resources.

\section{The Student Relationship Themes}

The student relationship themes explain that having good student relationships between teachers have created a positive and conducive school organizational climate. According to Mutiara and Sobandi (2018) the school climate plays an important role in developing a healthy and positive school environment. A positive climate will elevate the valuable process of teaching and learning between teachers and students. Their research also found that the school organization climate is considered positive when it comes to features such as a productive working environment, good social relationships among school children, comfortable environment, school cleanliness and attractive layout and landscape. One of the respondents suggest that student-teacher relationship plays an important role of better school organizational climate;

I've been working with three different schools since I was a teacher 15 years ago. Compared to other school environments, I've found that this school climate is very enjoyable where students have a close relationship with teachers and administrators. The students are very polite and well behaved both in the classroom and outside the school compound. As a teacher, you feel valued when your students appreciate what you've taught them. The relationship with the students made me feel like I was there for them. This school environment has helped me to be satisfied with my working conditions.

This result is also confirmed by the results of Virtanen, Vaaland, \& Ertesvåg (2019) study, which shows that the quality of teacher-student interaction is strongly linked to the satisfaction of teachers at work. In addition, Toropova, Myrberg, and Johansson (2020) found that the three main factors most associated with teacher job satisfaction are teacher workload, teacher engagement and teacher perceptions of student discipline in school. Researchers In the global context, Sims (2018) analyzed data from Teaching and Learning International Survey (TALIS) in 35 countries around the world and found that student discipline and teacher cooperation were positively related to teacher job satisfaction in all countries. This clearly indicates that high teacher job satisfaction is highly dependent on good and positive organizational climate.

\section{The Collaboration Themes}

Collaborative themes mean that teachers and all school staff can support and communicate with others. Their good cooperation in teaching, teaching, socializing 
and working towards the mission and vision of the school within their working environment is considered to be satisfactory (Toropova, Myrberg, \& Johansson, 2020). Everyone plays their own parts to ensure that the goal of the school is achieved. Perhaps the head teacher is very supportive and willing to listen to any suggestions from the teachers to ensure that all teachers feel comfortable and, subsequently, to achieve the satisfaction of teaching (Wahab \& Abdullah, 2018). One of the interviewees agreed with the finding that:

The way my headmaster managed the school made me feel very welcome and appreciated at school. As a teacher, you can feel that the way he politely listens to our suggestions and opinions makes me feel like part of the administration. On the other hand, he gave us full support for how we conduct classes, and I feel very proud when I was around. This is because he's never making a bad comment to me, and he's always thinking about motivation and making me feel very comfortable with him. Perhaps his experience of being a leader for so many years has made him my ideal leader.

Hanaysha and Tahir (2016) favored the above-mentioned comment and argued that the definition of job satisfaction is defined as an agreeable or optimistic emotional condition as a result of the assertion of a job. School leadership and the school climate are therefore part of the affirmation criteria. A supportive headmaster therefore allows teachers to prepare themselves and enjoy working conditions (Wynn, 2019). Moreover, Eng Fei and Han (2018) also point out that the culture of successful schooling is determined by representatives who have influenced the evaluation and learning approach of students and teachers.

In addition, collaboration between administrators, teachers and students seems to have created a satisfactory organizational climate within the school. This will help to improve the academic achievement of the school (Katsantonis, 2019). Thus, if the climate of school organization is high, the influence of the teacher commitment on the school is also high. With the good commitment, perhaps influence their happiness towards their teaching works in school This strong partnership has also been agreed by Kariming and Ambatong (2018) who stated that in order to increase productivity and job satisfaction, a school must create a climate that promotes a high level of organizational climate, which is the link between all components of a school whether administrators with teachers, teachers with students and students with students. Additionally, good social interaction between teachers has also made it possible for teachers to benefit further. They will improve their innovation in teaching in order to improve student teaching aids.

\section{The Decision-Making Theme}

Teachers are appreciative of their school administration, which makes them feel safe and secure and contributes to a high level of job satisfaction (Valdez et al., 2019). As a result of their high job satisfactions, it can also increase their loyalty to the school. On the other hand, because of the good cooperation between the administration and the teachers, the head teacher gave the teachers the opportunity to 
present their ideas in certain decision-making processes. This kind of recognition made the teacher feel very much appreciated. One of the teachers said that "I am glad that I have been given the opportunity to give ideas on school decision making. I feel proud that my idea was recognized." This means that the decision-making dimension has an important relationship with the job satisfaction of the teacher. The decisionmaking process is based on interaction and collaboration between teachers and administrators. Teachers have a voice to determine the direction of the school. It is important to keep schools in a structure that is in good agreement with each other. School decisions are made on the basis of reciprocal deliberation between teachers and administrators. According to a study by Tahir, Mansor dan Darusalam (2018) school leaders should be able to motivate teachers to undertake exceptional school activities. They also found that headmaster's style of leadership has successfully changed the attitude of the teacher, as well as providing the teacher with unshakeable job gratification. This also proved, therefore, that collaborative decision between the administration and the teachers led to the extraordinary satisfaction of the teacher.

On the other hand, the authorities should therefore be aware that emotional dissonance is related to high emotional weakness, low organizational commitment and low job satisfaction. Teachers, headmaster, school authorities and educational staff should therefore work together to ensure that all parties benefit from a good school climate. In Addition, the headmaster who did not understand and appreciate the work of the teachers, which caused the teacher's organizational climate and working atmosphere to be negative. One of those who said he had been very dismayed;

In my school, however, I felt that the administrator was not fair to some of the teachers. She only recognized the work of a few teachers who had a good relationship with her. My friends and I have always been left out in making decisions, getting school resources, and as a class time table, we've always had to teach the problem, misbehaved and low student attendees. My suggestion is that the administration, as a leader, should be fair to all teachers and should perhaps give equal recognition without bias.

The above statement is also agreed by Nugraha (2019) who found that the head teacher does not appreciate the work of teachers, which will gradually have a negative impact on the job satisfaction of teachers. A head teacher who disrespects the members of the organization will make the organization's climate negative. This will have an indirect impact on the achievement of the school's objectives and will not be achieved. Therefore, organizational leaders should be responsible for building a positive atmosphere and motivating their employees to do so (Valdez, et al, 2019). This is also agreed by Aziz and Hussin (2017) who found that there was a significant relationship between the school climate and the level of satisfaction of the teacher's work. This relationship, therefore has a high impact on the satisfaction of teachers 'work. Teachers will be more eager to achieve the school goals agreed with the administration. This will make the school environment more positive, and ultimately the satisfaction of the teacher's work will also increase. 


\section{The Instructional Innovation Themes}

This implies that educational innovation has a significant relationship with the level of satisfaction of teachers. Instructional innovation means that teachers are constantly engaging and implementing new and different ideas in teaching and learning. Teachers are also constantly experimenting with the latest and innovative approaches to achieving school goals and self-fulfillment. Of course, with good cooperation between administrators and teachers, and the relationship between teachers and teachers, instruction innovation would be easier to develop and implement. The experience teacher, perhaps, will advise the novice teacher on teaching and teaching pedagogically, but the younger teacher, who is more literate in computer-based and IT-based, will provide a good innovative computer-based program. One of the teachers mentioned that, "The younger teachers who experts in IT helps us the older teacher on creating innovative teaching lesson through internet application. With their support, I'm so glad." As a result, this Instructional Innovation can also increase the high commitment of teachers to ensure that the teaching they teach is of interest to learners. Research by Vertanen et al (2019) found that teachers who have made progress have proclaimed higher initial educational support levels than non-improved teachers. Improved teachers also reported higher job satisfaction and less stress from misbehavior among students. This means, therefore, that teachers who improve the application of educational support are more satisfied in their work than those who have done so. This finding is consistent with a study by Yusoff and Saidin (2016) which found that the dimension of school climate organization is that educational innovation has a positive and significant relationship with the level of commitment of teachers. However, some teacher who don't have the ability of creating new innovative teaching materials might feel awkward, "I have no problem in teaching, I believe I can deliver perfectly to make my students understand and I am sure with my style of teaching my students performs excellently. But to ask me to be innovative especially using IT and computer-based technology, I am so sorry I am not trained to be IT expert."

\section{The School Resources Themes}

Result also shows that school resources were the lowest average score anticipated by teachers. School resources include student learning facilities such as resource centers, ICT rooms, science rooms, Self-Access Learning (SAL) rooms, music rooms and the Art and Visual Education Room (Ministry of Education, 2013). As a result, teachers seem to have the impression that their school resources are inadequate. "I love working here, but I feel more satisfy if the facilities in this school is up-to-date and adequate," said a school teacher. This shows that although the level of job satisfaction has been found to be high, they feel that their satisfaction will increase if the learning facilities adequately provided by the school authority. With learning resources, academic achievement of students will also improve on a regular basis. It is therefore also important to ensure that the resources of the school are sufficiently available. Similarly, a study conducted by Hassan and Wahab (2017) on job satisfaction found that secondary school teachers in the Bangsar Zone experienced moderate levels of job satisfaction due to the organizational climate, such teacher- 
student relationships between misbehaved students, inadequate school resources, and the school community activities are not sufficient. Based on the study by Hassan and Wahab, the school should ensure that the school's resources for teaching are sufficient for teachers to use them in teaching. In order to justify this, one of the respondent's appeals to the administration to improve its school teaching resources;

I believe my school should have better facilities for a science laboratory, an ICT room, a self-access center and a resource room. What we have is very old, and some of the facilities are no longer working. If it doesn't work, how are we going to teach the students more appropriately? It seems that my school's teaching resources facility is always inadequate, and this has been going on for more than six months. I don't know about any other school in the vicinity, but I thought my school was lacking in teaching resources...Personally, I hope that the administration should also try to find an alternative allocation for teaching and learning purposes.

The quotation indicates that teachers are willing to wait, but it is not acceptable if thefacilities have not been replaced for more than six months. As suggested, the head mistress should find alternative ways to overcome the problem without waiting for the Department of Education to remedy it. Perhaps, what she can suggest to the parent-teacher association is to raise money to overcome the problems. At the same time, of course, the head mistress should repeatedly ask the State Department of Education to replace the defective equipment. Poor resources, on the other hand, do not involve the entire population of the study. Some schools have sufficient and adequate learning facilities, one teacher said, "The priority of my head teacher is to make sure the teaching resources is adequate." Another teacher said, "Although other school has problem with teaching resources, but my school has no problem." According to Kariming and Ambatong (2018), organizations and institutions need better production tools. Besides the supportive climate, the administration should not ignore school adequate facilities to ensure teacher satisfaction. Teachers are unhappy with the insufficient school facilities. It is vital to ensure that a satisfactory level of education among primary school teachers in this school district is continually improved.

\section{CONCLUSION}

Based on the interview result and the quantitative survey data, it appears that there is not so much difference between the two methodologies. This is due to the fact that the questions created for interviews were based on the previous findings of the literature review. The findings show that the job satisfaction of the teacher is positively related to the organizational climate. It seems that the teachers in this study are delighted with the work because of the organizational environment. The main findings show that the relationship between a student and a teacher shows a vital contribution to good relationship with a teacher's job satisfaction. This shows that the student's attitude, behavior and willingness to learn has made the teacher feel proud and willing to spend more time with them. This is agreed with the research of Toropova, et al., (2020), who found that among the organizational climate components, school work environment, teacher workload, teacher co-operation, and student discipline were the key reasons that lead to satisfactory teacher work. The 
five dimensions (i.e. student relationship, collaboration, decision-making, educational innovation, and school resources) have emerged which are interrelated for both quantitative and qualitative methodologies. More than that, the Sim (2017) study found that student behavior and teacher cooperation were highly related to teacher job satisfaction in their study. Similar result found in this study, where the relationship between students and teachers is related to job satisfaction. Next, the collaboration between teachers and teachers, and teachers with the administration also give impacts to teacher job satisfaction (c.f., Wahab \& Abdullah, 2018). On the other hand, head teachers also play important roles for teacher job satisfaction especially in appreciating teacher decision making in the school management (c.f., Valdez et al., 2019). Whereas, the innovation technology plays a good relationship but also have mix findings where negative perception is quite high (c.f., Vertanen et al, 2019). Moreover, the finding is similar to Hassan and Wahab (2017) who also proposed that school resources should be adequate in order to ensure students benefits in academic achievements. Out of the above valuable findings, one important contribution to this study is that the head teacher has given teachers a chance to make decisions that have made teachers feel respected and recognized. This means that the teachers involved in the study are directly involved in defining the direction and objectives of the school. This will make the school environment more positive and ultimately increase the satisfaction of teachers at work.

\section{LIMITATION OF THE STUDY}

This study has its own limitations which need to be identified in order to improve the job satisfaction and organizational climate of the school. However, this study has limitations: first, the results showed that the climate of the school organization was closely linked to the level of satisfaction of the teachers 'work. Researchers therefore suggest that further studies will be conducted using a larger number of respondents to provide a more accurate and clearer picture. Next, the location factor of the school, researchers suggest that other researchers will study the difference between rural and urban school locations. In comparison to this study, this will be able to produce different findings. In addition, researchers also recommend that this study not only focus on primary schools but also extend to secondary schools, high-performance schools and boarding schools, where students are selected to be excellent students. Moreover, the unification between the organizational climate of the school and the different attributes of the teacher is complex, and the personal characteristics of each individual need to be thoroughly analysed. Close attention to this clearly helps to understand the nature of job satisfaction. Finally, a cross-section design and interview design may not allow for an original conclusion. A more complex approach should therefore include longitudinal studies throughout Malaysia.

\section{RECOMMENDATION}

To conclude, this study contributes to the new knowledge in education management by exploring the link between the school's organizational environment and teacher job satisfaction with reference primary school teacher settings. Literature confirms that the organizational environment of good leadership will encourage and empower 
their followers with job satisfaction in work and development. More specifically, the results of this study will help administrators, educators and stakeholders to gain a deeper insight into vision creation and leaders focused on developing and promoting a better school environment. According to Maiti (2019); Mukhtar (2020); Wynn (2019) all staff including teachers, school administrators, support staff, and students should realized that poor school organizational climate will contribute to work dissatisfaction, and thus, indirectly will be discourage the whole organization to achieve the organizational goals.

\section{REFERENCES}

Amedome, N. S. (2018). The influence of leadership on school climate: A case of senior high schools in Hohoe Municipality of Ghana. Academy of Educational LeadershipJournal, 22(2). Retrievedfrom ttps://www.abacademies.org/articles/

Aziz, K. A., \& Hussin, F. (2016). Pengaruh iklim organisasi terhadap kepuasan kerja guru di sekolah menengah dalam daerah Kuala Terengganu [The influence of organizational climate on teacher work satisfaction at a secondary school in the Kuala Terengganu district]. Proceeding of the ICECRS, 1(1), 49-58.

Azmi, I. A. G., \& Siren, N. R. (2018). Job satisfaction level of non-government Islamic religious school teachers. Akademika, 88(2), 35-58.

Bai, N., Piri, R., \& Piri, A. (2014). Investigating school organizational climate and job satisfaction from Kalale physical education teachers' point of view. Research Journal of Sport Science, 2(2), 45-49.

Eh Tem, W. N. (2013). Pengaruh iklim organisasi ke atas prestasi kerja guru di kolej vokasional [The influence of organizational climate on teacher work performance in vocational colleges]. Master Thesis. Universiti Tun Hussein Onn Malaysia.

Eng Fei, E. L., \& Han, C. G. k. (2018). The Relationship of Principals’ Leadership and School Climate with Teachers' Motivation. Malaysian Journal of Social Sciences and Humanities (MJSSH), 3(2), 1 - 16.

Entoh, H., \& Abdullah, M. K. (2019). Pengaruh iklim organisasi sekolah terhadap kesedaran metakognisi dalam kalangan guru-guru sekolah rendah di zon Pulau, Utara Sabah [The influence of school organization climate on awareness metacognition among primary school teachers in the Sabah, North Sabah zone]. Malaysian Journal of Social Sciences and Humanities, 4(1), 60-73.

Hamdan, F. L., \& Hamzah, M. I. M. (2016). Pengaruh iklim organisasi terhadap kepuasan kerja dalam kalangan pensyarah Kolej Poly-tech Mara (KPTM) [The influence of organizational climate on job satisfaction among the Poly-tech Mara College (KPTM) lecturers]. Global Summit on Education, 4(3), 304-313.

Hanaysha, J., \& Tahir, P. R. (2016). Examining the effects of employee empowerment, teamwork, and employee training on job satisfaction. Procedia-Social and Behavioral Sciences, 219, 272-282. 0.1016/j.sbspro.2016.05.016. 
Hardianto, H. (2019). Optimalisasi kepuasan kerja guru [Optimization of teacher job satisfaction]. Jurnal Manajemen Pendidikan, 5(2), 190-195.

Hassan, N., \& Wahab, J. M. (2017). Kepuasan kerja dalam kalangan guru di sekolah menengah zon Bangsar [Job satisfaction among teachers at Bangsar zone high school]. Seminar Pendidikan Serantau Ke-viii, 401-408.

Johnsons, B., Stevens, J., \& Zvoch, K. (2007). Teachers' perceptions of schoolclimate: A validity study of scores from the Revised School Level Environment Questionnaire. Educational and Psychological Measurement, 67, 833844. Doi.10.1177/0013164406299102.

Judge, T. A., Weiss, H. M., Kammeyer-Mueller, J. D; \& Hulin, C. L. (2017).Job attitudes, job satisfaction, and job affect: A century of continuity and of change. $J$ Appl Psychol, 102(3), 356-374. doi: 10.1037/ap10000181. Epub 2017 Jan 26

Kapa, R., \& Gimbert, B. (2017). Job satisfaction, school rule enforcement and teacher victimization. School Effectiveness and School Improvement, 29(1), 150168. doi:10.1080/09243453.2017.1395747

Kariming, N., \& Ambotang, A. S. (2018). Hubungan iklim sekolah terhadap kepuasan kerja guru tingkatan 6 zon Pantai Timur Sabah [Relationship of school climate to job satisfaction of 6th grade East Coast Sabah teachers]. Jurnal Komunikasi Borneo, 6, 53-64.

Katsantonis, I. G. (2019). Investigation of the impact of school climate and teachers' self-eficacy on job satisfaction: A cross-cultural approach. European Journal of Investigation in Health Psychology Education, 10, 119-133.

Krejcie, R.V., \& Morgan, D.W. (1970). Determining sampel size for research activities. Educational and Psychological Measurement, 30, 607-610.

Lester, P. E. (1987). Development and factor analysis of the teacher job satisfaction questionnaire (TJSQ). Educational and Psychological Measurement, 47(1), 223-233.

Locke, E.A. (1969). What is job satisfaction? Organizational Behavior and Human Performance,4(4), 309-336.

Maiti, G. (2019). Relationship between primary teachers' job satisfaction and their organizational climate in Kharagpur-i, district Paschim Medinipur. Indian Journal of applied Research, 9(11), 19-20.

McLaughlin, J. (2018). What is organizational culture. Available from https://study.com/academy/[Accessed [Accessed 403 2020].

Ministry of Education. (2013). Pelan Pembangunan Pendidikan Malaysia 20132025 [Malaysian Education Development Plan 2013-2025]. Putrajaya: Ministry of Education.

Mukhtar, M. (2020). Role of organizational climate in managing job satisfaction among academic staff: empirical evidence from education sector of Pakistan. Int $J$ Adv Res Manage Comput Sci, 1(1), 5-1. 
Mutiara, N. U., \& Sobandi, A. (2018). Iklim sekolah sebagai determinan minat belajar Siswa [School climate as a determinant of learning interest Students]. Jurnal Pendidikan Manajemen Perkantoran, 3(1), 218-225.

Nugraha, M. F. (2019). Iklim organisasi dan kepuasan kerja guru di sekolah Singosari Delitua [Organizational climate and teacher job satisfaction in Schools Singosari Delitua]. Jurnal Diversita, 5(1), 19-23.

Sims, S. (2018). Essays on the recruitment and retention of teachers (Doctoral dissertation). University College London.

Stewart, C. B., \& Robles-Piña, R. (2008). Black and blue: The impact of nonfatal teacher victimization. The Journal of At-Risk Issues, 14(2), 9-15.

Tahir, A., Mansor, A. Z., \& Darusalam, G. (2018). Amalan kepimpinan transformasional guru besar dan hubungannya terhadap kepuasan kerja guru sekolah daerah Miri [Leadership practice transformational headmaster and its relation to teacher job satisfactioMiri district school]. Seminar Antarabangsa Isu-Isu Pendidikan, 12-22.

Toropova, A., Myrberg, E., \& Johansson, S. (2020): Teacher job satisfaction: the importance of school working conditions and teacher characteristics, Educational Review, DOI: 10.1080/00131911.2019.1705247

Valdez, A. V., Guro, A. P., Cana, N. H., \& Lawi, L. M. (2019). School organizational climate and job satisfaction of MSU junior high school teachers. International Journal of Science and Management Studies (IJSMS), 2(1), 92-99.

Virtanen, T., Vaaland, G. S., \& Ertesvåg, S. K. (2019). Associations between patterns of Observed classroom interactions and teacher well-being. Teaching and Teacher Education, 77, 240-252.

Wahab, N. A., \& Abdullah, M. Y. (2018). Hubungan gaya kepimpinan dan pengurusan kerja guru besar dengan kepuasan kerja guru sekolah agama kerajaan Johor [Relationship style leadership and management of the work of the headmaster with the satisfaction of the work of the government religious school teacher Johor]. Journal of Ilmi, 8, 136-150.

Wynn, S. C. (2019). What research says about leadership styles and their implications for school climate and teacher job satisfaction. (Master of Education), Cedarville University.

Yusoff, S.M., \& Saidin, K. (2016). Tahap iklim sekolah, tahap komitmen guru serta hubungan di antara iklim sekolah dengan komitmen guru sekolah-sekolah menengah daerah machang, Kelantan [School climate level, teacher commitment level and the relationship between school climate and teacher commitment in machang, secondary schools]. Proceeding of ICECRS, 1 (2016) International Seminar on Generating Knowledge Through Research, UUM-UMSIDA, 25-27 October 2016, Universiti Utara Malaysia, Malaysia, 635-646 